\title{
Identification of Lactobacilli from Sourdough and Description of Lactobacillus pontis sp. nov.
}

\author{
RUDI F. VOGEL, ${ }^{1 *}$ GEORG BÖCKER, ${ }^{1}$ PETER STOLZ, ${ }^{1}$ MATTHIAS EHRMANN ${ }^{2}$ \\ DANIELA FANTA, ${ }^{2}$ WOLFGANG LUDWIG, ${ }^{2}$ BRUNO POT, ${ }^{3}$ KAREL KERSTERS, ${ }^{3}$ \\ KARL HEINZ SCHLEIFER, ${ }^{2}$ AND WALTER P. HAMMES ${ }^{1}$
}

Institut für Lebensmitteltechnologie, Universität Hohenheim, 70599 Stuttgart, ${ }^{1}$ and Lehrstuhl für Mikrobiologie, Technische Universität München, 80290 Munich, ${ }^{2}$ Germany, and Laboratorium voor Microbiologie, Rijksuniversiteit Gent, B 9000 Ghent, Belgium $^{3}$

\begin{abstract}
The microflora of sourdough preparations was investigated by examining the physiological characteristics, whole-cell protein patterns, and 16S rRNA sequences of Lactobacillus isolates. Strains isolated from sourdough were placed in the species Lactobacillus brevis, Lactobacillus sanfrancisco, and Lactobacillus reuteri. 16S rRNA sequences were determined for $L$. brevis, Lactobacillus fructivorans, Lactobacillus fermentum, L. sanfrancisco, and $L$. reuteri, and oligonucleotide probes for fast specific identification of these sourdough lactobacilli were deduced. The physiological characteristics, protein patterns, and 16S rRNA sequences of these organisms were compared with data for other sourdough lactobacilli and additional reference strains. Strains of a Lactobacillus species were isolated from rye sourdough; these strains may account for most of the flora in sourdough made from wheat or rye. These organisms were differentiated from other sourdough lactobacilli by their protein pattern, 16S rRNA sequence, $G+C$ content, and physiological properties. The 16S rRNA sequence of this species was determined, and we constructed a phylogenetic tree which reflected the relationships of this species to other lactobacilli. This organism is closely related to L. reuteri. A new Lactobacillus species, Lactobacillus pontis, is proposed. The type strain is L. pontis LTH 2587 (= DSM 8475 = LMG 14187). We describe a general strategy in which a polyphasic approach was used to characterize a new species.
\end{abstract}

Sourdough starter preparations are used to initiate and carry out the essential acidification of rye flour-containing doughs and, in addition, are traditionally used for flavoring wheat doughs. As these doughs are not prepared aseptically, their hygienic safety and high quality must be ensured by the use of well-defined, traditional process conditions. An understanding of the microbial ecology of sourdough is a prerequisite for the development of well-defined single- and multiple-strain preparations, as they are known in the dairy industry. "Lactobacillus brevis subsp. lindneri" has been identified as the typical organism in rye sourdough $(18,19)$, whereas the characteristic organism in wheat sourdough was described as the new species Lactobacillus sanfrancisco by Kline and Sugihara (10). Subsequently, the "L. brevis subsp. lindneri" strains were placed in the species $L$. sanfrancisco (21). These organisms account for most of the microbial flora in sourdough (2). L. sanfrancisco can be distinguished from $L$. brevis and "Lactobacillus lindneri" by the different amino acids in the interpeptide bridge of the peptidoglycan. $L$. sanfrancisco contains L-alanine, whereas $L$. brevis and " $L$. lindneri" contain D-aspartic acid in their interpeptides (15).

In our experience, $L$. sanfrancisco, strains of $L$. brevis, Lactobacillus fermentum, and Lactobacillus fructivorans are the predominant organisms in sourdough. Taxonomic identification of these organisms by traditional methods, such as sugar fermentation patterns and cell wall analysis, is time consuming and not very reliable. Some of the organisms hardly grow on laboratory media and may escape isolation, and they cannot be identified by standard procedures. Thus, the composition of the microbial flora in these environments is difficult to deter-

\footnotetext{
* Corresponding author. Present address: Lehrstuhl für Technische Mikrobiologie, Technische Universität München, 85350 FreisingWeihenstephan, Germany. Phone: 49816171 3284. Fax: 49816171 4418 .
}

mine. On the other hand, knowledge concerning the composition of the microflora is an essential prerequisite for ecological and metabolic studies. Finally, these organisms influence the sensory quality of the bread as the metabolic products formed are strongly affected by the ratio of homofermentative lactobacilli to heterofermentative lactobacilli, and the organisms may influence the quality of the sourdough.

In this paper we describe the use of whole-cell protein pattern analysis and $16 \mathrm{~S}$ rRNA sequence analysis in combination with physiological data to characterize taxonomic relationships among lactobacilli isolated from sourdough. Moreover, we designed $16 \mathrm{~S}$ rRNA-targeted oligonucleotide probes for rapid identification of the relevant species, including Lactobacillus pontis sp. nov.

\section{MATERIALS AND METHODS}

Organisms and growth conditions. The bacterial strains investigated and the strains used to construct and evaluate the specificity of the probes are listed in Table 1. The organisms used in the taxonomic evaluation of sourdough lactobacilli are shown in Fig. 1. Strains were grown in sanfrancisco medium, which contained (per liter) $10 \mathrm{~g}$ of tryptone, $2 \mathrm{~g}$ of meat extract, $7 \mathrm{~g}$ of yeast extract, $7 \mathrm{~g}$ of glucose, $7 \mathrm{~g}$ of fructose, $7 \mathrm{~g}$ of maltose, $2 \mathrm{~g}$ of sodium gluconate, $5 \mathrm{~g}$ of sodium acetate $\cdot 3 \mathrm{H}_{2} \mathrm{O}$, $5 \mathrm{~g}$ of citric acid (diammonium salt), $2.5 \mathrm{~g}$ of $\mathrm{KH}_{2} \mathrm{PO}_{4} \cdot 3 \mathrm{H}_{2} \mathrm{O}$, $0.2 \mathrm{~g}$ of $\mathrm{MgSO}_{4} \cdot 7 \mathrm{H}_{2} \mathrm{O}, 0.05 \mathrm{~g}$ of $\mathrm{MnSO}_{4} \cdot 4 \mathrm{H}_{2} \mathrm{O}, 0.01 \mathrm{~g}$ of $\mathrm{FeSO}_{4} \cdot 7 \mathrm{H}_{2} \mathrm{O}, 0.5 \mathrm{~g}$ of cysteine $\mathrm{HCl}, 1 \mathrm{~g}$ of Tween $80,21 \mathrm{~g}$ of fresh baker's yeast, and $50 \mathrm{~g}$ of rye or wheat bran; the $\mathrm{pH}$ was 5.4. When this medium was used as a broth medium, solid compounds were removed after autoclaving and centrifugation twice for $15 \mathrm{~min}$ at $5,000 \times \mathrm{g}$. Alternatively, cells were grown in modified MRS medium, which contained (per liter) $10 \mathrm{~g}$ of tryptone, $5 \mathrm{~g}$ of meat extract, $5 \mathrm{~g}$ of yeast extract, $7 \mathrm{~g}$ of glucose, $7 \mathrm{~g}$ of fructose, $7 \mathrm{~g}$ of maltose, $2 \mathrm{~g}$ of sodium gluconate, $5 \mathrm{~g}$ of sodium acetate $3 \mathrm{H}_{2} \mathrm{O}, 2 \mathrm{~g}$ of citric acid (diammonium salt), 
TABLE 1 . Specificity of oligonucleotide probes

\begin{tabular}{|c|c|c|c|c|c|c|c|}
\hline \multirow[b]{2}{*}{ Strain } & \multicolumn{7}{|c|}{ Reaction with ${ }^{a}$ : } \\
\hline & 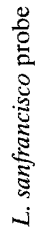 & 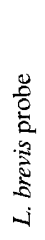 & 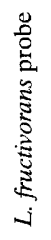 & 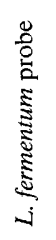 & 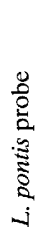 & 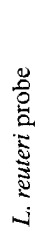 & 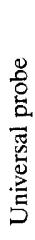 \\
\hline L. sanfrancisco ATCC $27651^{\mathrm{T} b}$ & + & - & - & - & - & - & + \\
\hline L. sanfrancisco ATCC 27652 & + & - & - & - & - & - & + \\
\hline L. sanfrancisco ATCC 27653 & + & - & - & - & - & - & + \\
\hline L. sanfrancisco DSM 20663 & + & - & - & - & - & - & + \\
\hline L. sanfrancisco LTH 671 & + & - & - & - & - & - & + \\
\hline L. sanfrancisco LTH 1728 & + & - & - & - & - & - & + \\
\hline L. sanfrancisco LTH 1729 & + & - & - & - & - & - & + \\
\hline L. sanfrancisco LTH 1730 & + & - & - & - & - & - & + \\
\hline L. sanfrancisco LTH 2582 & + & - & - & - & - & - & + \\
\hline Lactobacillus sp. strain LTH 2590 & + & - & - & - & - & - & + \\
\hline Lactobacillus sp. strain LTH 2594 & + & - & - & - & - & - & + \\
\hline Lactobacillus sp. strain LTH 2595 & + & - & - & - & - & - & + \\
\hline Lactobacillus sp. strain LTH 2598 & + & - & - & - & - & - & + \\
\hline L. reuteri DSM $20016^{\mathrm{T} b}$ & - & - & - & - & - & + & + \\
\hline Lactobacillus sp. strain LTH 2584 & - & - & - & - & - & + & + \\
\hline L. pontis LTH 2585 & - & - & - & - & + & - & + \\
\hline L. pontis LTH 2586 & - & - & - & - & + & - & + \\
\hline L. pontis LTH $2587^{\mathrm{T} b}$ & - & - & - & - & + & - & + \\
\hline L. pontis LTH 1731 & - & - & - & - & + & - & + \\
\hline L. pontis LTH 1735 & - & - & - & - & + & - & + \\
\hline L. brevis DSM $20054^{\mathrm{T} b}$ & - & + & - & - & - & - & + \\
\hline Lactobacillus sp. strain LTH 2588 & - & + & - & - & - & & + \\
\hline L. fructivorans DSM $20203^{\mathrm{T} b}$ & - & - & + & - & - & & + \\
\hline L. fructivorans LTH 669 & - & - & + & - & - & - & + \\
\hline L. homohiochii DSM $20571^{\mathrm{T}}$ & - & - & + & - & - & - & + \\
\hline L. fermentum DSM $20052^{\mathrm{T} b}$ & - & - & - & + & - & - & + \\
\hline
\end{tabular}

${ }^{a}$ The probes were deduced from the $16 \mathrm{~S}$ rRNA sequences of the organisms. The following strains did not react with any of the probes: Lactobacillus acidophilus DSM $20079^{\mathrm{T}}$, Lactobacillus alimentarius DSM $20249^{\mathrm{T}}$, Lactobacillus buchneri DSM $20057^{\mathrm{T}}$, Lactobacillus casei subsp. casei DSM $20011^{\mathrm{T}}$, Lactobacillus rhamnosus DSM $20021^{\mathrm{T}}$, Lactobacillus delbrueckii subsp. bulgaricus DSM $20081^{\mathrm{T}}$, Lactobacillus delbrueckii subsp. delbrueckii DSM 20074 ${ }^{\mathrm{T}}$, Lactobacillus delbrueckii subsp. lactis DSM $20072^{\mathrm{T}}$, Lactobacillus farciminis DSM $20184^{\mathrm{T}}$, Lactobacillus hilgardii DSM $20176^{\mathrm{T}}$, "L. lindneri" LTH 2505, "Lactobacillus pastorianus" DSM 20197, Lactobacillus plantarum DSM 20174 ${ }^{\mathrm{T}}$, L. plantarum DSM 20205, Lactobacillus viridescens DSM $20410^{\mathrm{T}}$, Leuconostoc mesenteroides subsp. dextranicum DSM 20484 $4^{\mathrm{T}}$, and Pediococus acidilactici DSM $20333^{\mathrm{T}}$.

${ }^{b}$ Strain used to design a probe.

$2.6 \mathrm{~g}$ of $\mathrm{K}_{2} \mathrm{HPO}_{4} \cdot 3 \mathrm{H}_{2} \mathrm{O}, 0.1 \mathrm{~g}$ of $\mathrm{MgSO}_{4} \cdot 7 \mathrm{H}_{2} \mathrm{O}, 0.05 \mathrm{~g}$ of $\mathrm{MnSO}_{4} \cdot 4 \mathrm{H}_{2} \mathrm{O}, 0.5 \mathrm{~g}$ of cysteine $\mathrm{HCl}$, and $1 \mathrm{~g}$ of Tween 80 ; the $\mathrm{pH}$ was 6.3. Solid media contained agar ( $15 \mathrm{~g} /$ /iter $)$.

Physiological characterization. Sugar fermentation patterns were determined by using the API 50 system (API, Biomerieux, Nürtingen, Germany). Cell walls were isolated by the method of Schleifer and Kandler (16). The amino acids of the cell walls were determined by the FMOC method (1). Other physiological properties were determined by the methods described by Kandler and Weiss (8) and Hammes et al. (6). The DNA $\mathrm{G}+\mathrm{C}$ contents of lactobacilli were determined performed by high-performance liquid chromatography at the Deutsche Sammlung von Mikroorganismen und Zellkulturen,
Braunschweig, Germany. An electron micrograph was taken with Formvar-coated EM grids carrying dried, nonstained cells that were in a solution containing $1 \mathrm{~g}$ of tryptone per liter and $8.5 \mathrm{~g}$ of $\mathrm{NaCl}$ per liter and were fixed with $1 \%$ glutaraldehyde and a model CEM 902 energy-filtering transmission electron microscope (Zeiss, Jena, Germany).

Protein pattern analysis. To cultivate bacteria for sodium dodecyl sulfate (SDS)-polyacrylamide gel electrophoresis, cultures were grown in Roux flasks containing 120-ml portions of sterile MRS agar (Oxoid) and inoculated with 10-ml portions of a 24-h-old MRS broth culture; the flasks were incubated aerobically for $24 \mathrm{~h}$ at $30^{\circ} \mathrm{C}$. Then, $30 \mathrm{ml}$ of sodium phosphatebuffered saline $\left(40.5 \mathrm{ml}\right.$ of $\mathrm{Na}_{2} \mathrm{HPO}_{4} \cdot 12 \mathrm{H}_{2} \mathrm{O}[0.2 \mathrm{~mol} / \mathrm{liter}]$, $9.5 \mathrm{ml}$ of $\mathrm{NaH}_{2} \mathrm{PO}_{4} \cdot 2 \mathrm{H}_{2} \mathrm{O}[0.2 \mathrm{~mol} / \mathrm{liter}], 8 \mathrm{~g}$ of $\mathrm{NaCl}$, and enough double-distilled water to bring the final volume up to 1 liter) was added to each Roux flask, and the bacterial lawn was harvested with a bent glass rod, filtered through nylon gauze into a centrifuge tube, and centrifuged with a Sorvall model RC-2 centrifuge at $10,000 \mathrm{rpm}$ by using a type SS34 rotor. The resulting pellet was washed twice in the same way.

Preparation of cell extracts. About 70 to $80 \mathrm{mg}$ (wet weight) of bacterial cells was suspended in $0.9 \mathrm{ml}$ of sample treatment buffer $(0.75 \mathrm{~g}$ of Tris, $5 \mathrm{ml}$ of $\beta$-mercaptoethanol, $10 \mathrm{ml}$ of glycerol, and enough double-distilled water to bring the final volume up to $100 \mathrm{ml}$; $\mathrm{pH} \mathrm{6.8)}$ in an Eppendorf tube and sonicated for $3 \mathrm{~min}$ on ice with a Labsonic 2000 sonicator (Braun, Melsungen, Germany) by using a needle probe tip (length, $127 \mathrm{~mm}$; diameter, $4 \mathrm{~mm}$ ) and the "LOW" position at a maximum output of $50 \mathrm{~W}$. Subsequently, $0.1 \mathrm{ml}$ of a $20 \%$ (wt/vol) SDS solution was added, and the mixture was vortexed and heated for $10 \mathrm{~min}$ at $95^{\circ} \mathrm{C}$. After cooling and centrifugation for $10 \mathrm{~min}$ at $10,000 \mathrm{rpm}$, the supernatant was stored at $-12^{\circ} \mathrm{C}$ for immediate use or at $-80^{\circ} \mathrm{C}$ for long-term storage. Electrophoresis was performed as described by Laemmli (11) by using a $12 \%$ (wt/vol) polyacrylamide-SDS gel slab. Gels were dried with a Bio-Rad model 224 slab dryer.

Quantitative comparison of the protein electrophoretic patterns and construction of the data base. Protein electropherograms were scanned and digitized by using an Ultroscan laser densitometer (LKB, Bromma, Sweden) linked to a Commodore personal computer equipped with an analog-to-digital converter interface card. Data were registered, processed, and stored in data base format by using the GELCOMPAR software package (version 2.0) (20). The normalized traces (using points 10 to 320 of the 400 points of each interpolated trace) were compared quantitatively by using the techniques described by Kersters and De Ley (9) and Pot et al. (14). The levels of similarity between pairs of traces were expressed by the Pearson product moment correlation coefficient, and clustering was performed by the unweighted pair group method, using average linkage (17).

16S rRNA sequence analysis. Genomic DNA was extracted and purified as described by Lewington et al. (12). In vitro amplification and sequence determinations of almost complete $16 \mathrm{~S}$ rRNA genes were performed as described previously (22).

Phylogenetic analysis. The $16 \mathrm{~S}$ rRNA primary structures were added to an alignment of 1,500 homologous bacterial sequences. Distance matrix and parsimony analyses of a set that included all available $16 \mathrm{~S}$ rRNA sequences from gram-

FIG. 1. Mean correlation coefficient dendrogram. The mean correlation coefficients were calculated by the unweighted average pair group method for all strains investigated. Points 10 to 320 of the 400 -point traces were used to calculate levels of similarity for individual pairs of traces. For every species or subspecies the number of strains used is indicated in parentheses. The protein pattern of the type strain of each of the species falls into its respective cluster. 


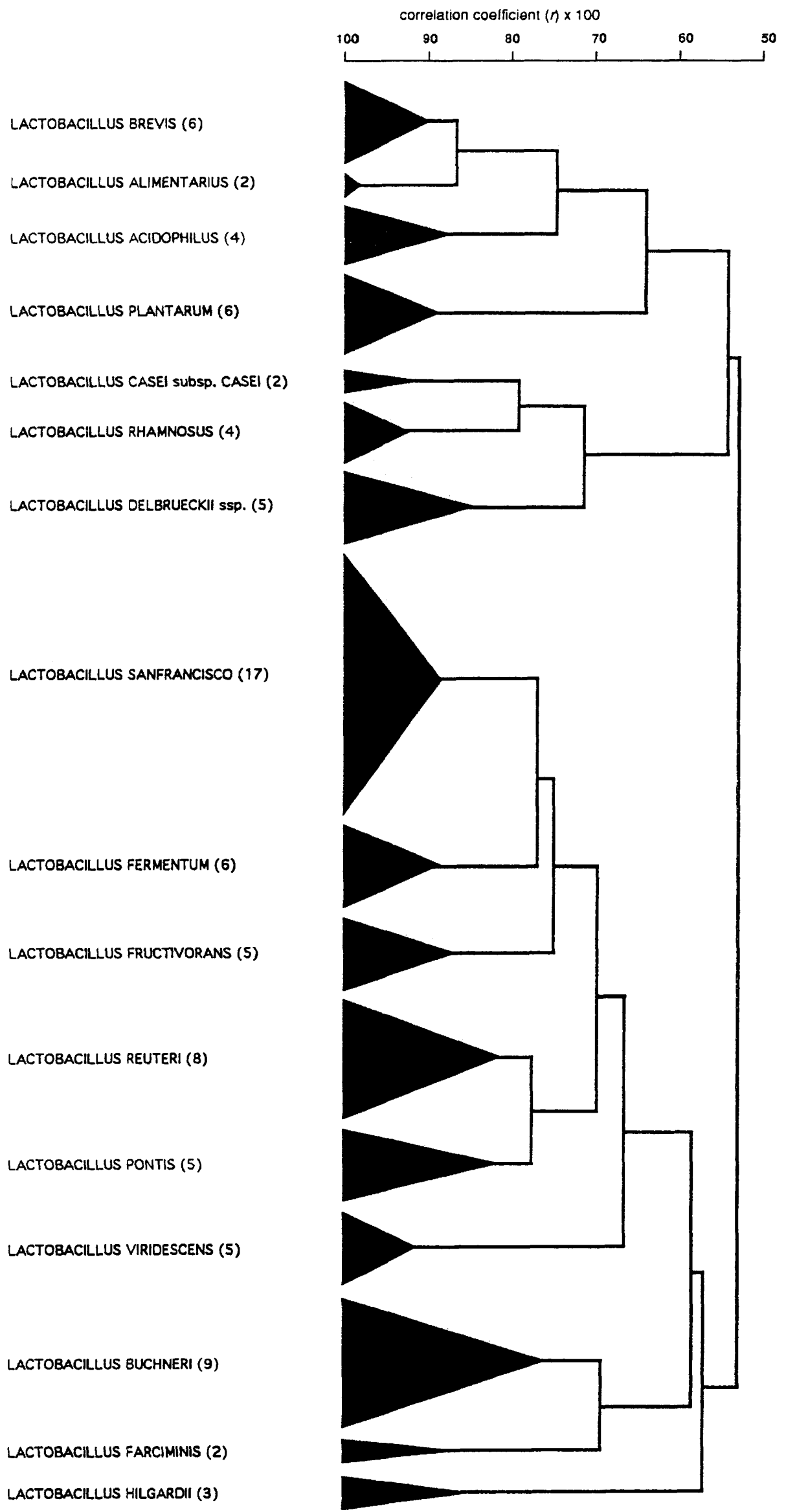


TABLE 2. Matrix of overall 16S rRNA sequence similarity values for Lactobacillus spp. and Escherichia coli

\begin{tabular}{|c|c|c|c|c|c|c|c|c|c|c|c|c|c|c|c|c|}
\hline \multirow[b]{2}{*}{ Taxon } & \multicolumn{16}{|c|}{$\%$ rRNA sequence similarity with: } \\
\hline & $\begin{array}{l}3 \\
\vdots \\
\vdots \\
j\end{array}$ & 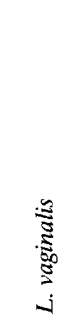 & & 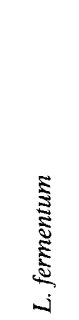 & 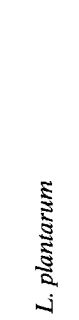 & 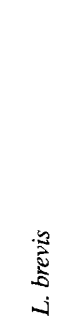 & 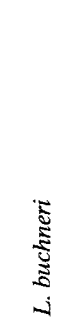 & 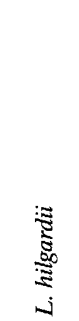 & 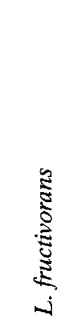 & 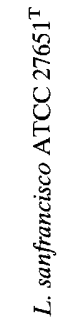 & 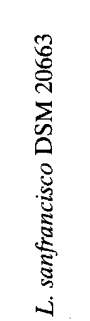 & 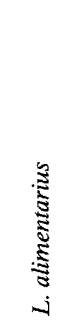 & 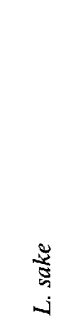 & 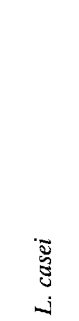 & 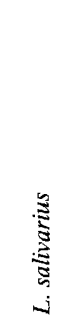 & $\begin{array}{l}\dot{8} \\
\text { (j) }\end{array}$ \\
\hline L. pontis & 96.32 & 96.79 & 96.29 & 92.72 & 90.15 & 90.92 & 90.63 & 90.36 & 90.86 & 89.51 & 89.51 & 88.94 & 90.53 & 90.37 & 88.12 & 77.73 \\
\hline L. oris & & 97.11 & 96.08 & 92.86 & 90.23 & 90.67 & 92.09 & 92.04 & 91.25 & 89.56 & 89.49 & 89.42 & 91.26 & 91.17 & 89.50 & 78.36 \\
\hline L. vaginalis & & & 96.42 & 92.83 & 90.94 & 90.79 & 91.33 & 91.61 & 91.15 & 89.44 & 89.44 & 89.65 & 91.26 & 90.71 & 88.78 & 77.12 \\
\hline L. reuteri & & & & 93.97 & 90.45 & 90.69 & 90.32 & 90.71 & 90.91 & 89.49 & 89.49 & 88.99 & 91.27 & 90.86 & 88.51 & 78.03 \\
\hline L. fermentum & & & & & 90.85 & 91.19 & 90.68 & 89.92 & 90.85 & 89.48 & 89.48 & 89.99 & 90.69 & 89.75 & 89.25 & 77.08 \\
\hline L. plantarum & & & & & & 93.61 & 91.99 & 92.05 & 92.41 & 91.28 & 91.28 & 93.29 & 92.30 & 91.49 & 90.03 & 77.21 \\
\hline L. brevis & & & & & & & 94.12 & 93.80 & 92.99 & 91.11 & 91.24 & 91.47 & 91.57 & 91.12 & 90.58 & 76.50 \\
\hline L. buchneri & & & & & & & & 97.42 & 94.05 & 92.08 & 91.93 & 90.71 & 91.58 & 91.90 & 91.27 & 77.10 \\
\hline L. hilgardii & & & & & & & & & 93.28 & 91.55 & 91.32 & 90.91 & 91.69 & 92.42 & 90.88 & 76.85 \\
\hline L. fructivorans & & & & & & & & & & 94.64 & 94.64 & 90.54 & 91.36 & 91.01 & 90.28 & 77.82 \\
\hline L. sanfrancisco ATCC $27651^{\mathrm{T}}$ & & & & & & & & & & & 99.75 & 89.50 & 89.21 & 90.18 & 89.71 & 77.20 \\
\hline L. sanfrancisco DSM 20663 & & & & & & & & & & & & 89.43 & 89.14 & 90.05 & 89.57 & 77.13 \\
\hline L. alimentarius & & & & & & & & & & & & & 90.70 & 90.06 & 89.80 & 76.59 \\
\hline L. sake & & & & & & & & & & & & & & 92.52 & 90.45 & 77.08 \\
\hline L. casei & & & & & & & & & & & & & & & 90.55 & 78.07 \\
\hline L. salivarius & & & & & & & & & & & & & & & & 77.22 \\
\hline
\end{tabular}

positive bacteria with low DNA $\mathrm{G}+\mathrm{C}$ contents $(3,13)$ were performed by using Felsenstein's (4) PHYLIP program package. The fastDNAml program (13) was used for maximum likelihood analysis of a smaller data set that included $16 \mathrm{~S}$ rRNA sequences of selected representatives of lactobacilli.

Design and application of rRNA-targeted specific probes. A comparative analysis of aligned $16 \mathrm{~S}$ rRNA sequences revealed diagnostic regions which were used as target sites for speciesspecific oligonucleotide probes. The oligonucleotides were obtained from MG W, Ebersberg, Germany. The hybridization procedures used have been described previously (7).

Nucleotide sequence accession numbers. The EMBL accession numbers for the $16 \mathrm{~S}$ rRNA sequences of $L$. sanfrancisco ATCC $27651^{\mathrm{T}}(\mathrm{T}=$ type strain) and DSM 20663, L. fructivorans DSM $20203^{\mathrm{T}}, L$. reuteri DSM $20016^{\mathrm{T}}$, and Lactobacillus sp. strain LTH $2587^{\mathrm{T}}$ are X76327, X76331, X76330, $\mathrm{X} 76328$, and $\mathrm{X} 76329$, respectively.

\section{RESULTS}

To taxonomically evaluate the microbial populations in sourdough starter preparations, we used two groups of organisms. Group 1 contained the type strains of $L$. sanfrancisco, $L$. brevis, $L$. fermentum, and $L$. fructivorans, which were used to design the probes. For hybridization studies and protein pattern analyses additional well-characterized (type) strains of bacteria were included as reference organisms. The second group consisted of original isolates obtained from sourdough and sourdough starter preparations. Prior to this work some of these isolates were taxonomically identified to the species level (2) by using the discriminatory schemes described by Kandler and Weiss (8) and Hammes et al. (6). Additional isolates were initially characterized as Lactobacillus species only. These strains were typical organisms that were found in sourdough preparations and accounted for 30 to $80 \%$ of the microbial flora; they were used to check the effectiveness of probing and protein pattern analysis for strain identification.

Phylogenetic relationships of sourdough lactobacilli. The 16S rRNA sequences of $L$. sanfrancisco ATCC $27651^{\mathrm{T}}$ and DSM 20663, L. fructivorans DSM $20203^{\mathrm{T}}$, L. reuteri DSM $20016^{\mathrm{T}}$, and Lactobacillus sp. strain LTH $2587^{\mathrm{T}}$ were determined and deposited in the EMBL sequence data bank.

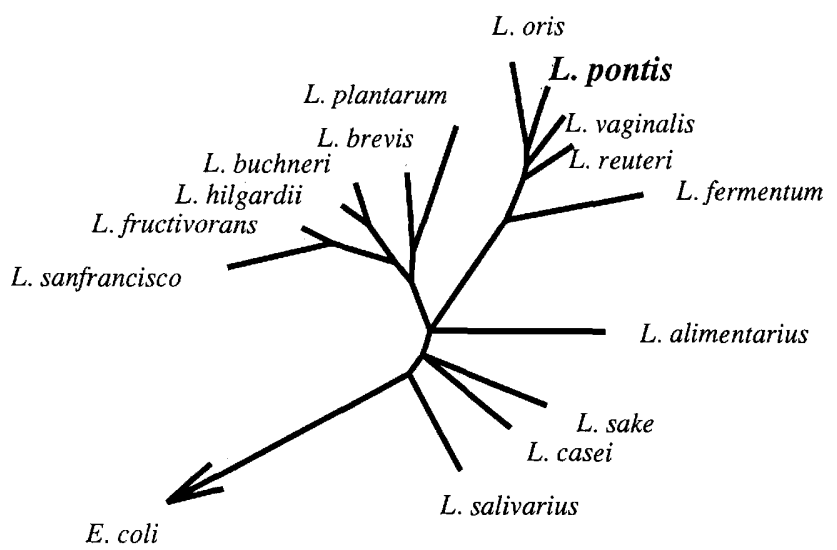

0.1

FIG. 2. Phylogenetic tree showing the phylogenetic relationships of L. pontis LTH $2587^{\mathrm{T}}$ and other lactobacilli. The 16S rRNA sequence of Escherichia coli was included as an outgroup reference rRNA. The tree was constructed by using a maximum-likelihood approach as implemented in the fastDNAml program of Olsen et al. (13). The tree was based on a data set that included only positions which are present in at least $50 \%$ of all available Lactobacillus $16 \mathrm{~S}$ rRNA sequences. Bar = 0.1 estimated substitution per sequence position. 
TABLE 3. Nucleotide sequences of and optimum hybridization conditions used for the 16S rRNA probes designed for identification of sourdough lactobacilli

\begin{tabular}{|c|c|c|c|c|}
\hline \multirow{2}{*}{ Probe } & \multirow{2}{*}{ Sequence } & \multirow{2}{*}{ Specificity } & \multicolumn{2}{|c|}{ Temp $\left({ }^{\circ} \mathrm{C}\right)$ used for: } \\
\hline & & & Hybridization & Washing \\
\hline L. sanfrancisco & $5^{\prime}$-TAAGAATCAATTGGGCGAC-3' & L. sanfrancisco & 40 & 47 \\
\hline L. farciminis & $5^{\prime}$-CTCGCTGCTAACTTAAGTC-3' & L. fructivorans & 40 & 50 \\
\hline L. fermentum & $5^{\prime}$-GCGACCAAAATCAATCAGG-3' & L. fermentum & 40 & 50 \\
\hline L. brevis & 5'-TGTTGAAATCAGTGCAAG-3' & L. brevis & 40 & 48 \\
\hline L. reuteri & $5^{\prime}$-GATCCATCGTCAATCAGG-3' & L. reuteri & 40 & 50 \\
\hline L. pontis & $5^{\prime}$-GGTAATCCATCGTCAAATC-3' & L. pontis & 40 & 49 \\
\hline 1037 & $5^{\prime}$-CGACAAGGAATTTCGCTAC-3' & Universal & 40 & 48 \\
\hline
\end{tabular}

Various parts of $16 \mathrm{~S}$ rRNA genes of Lactobacillus sp. strains LTH 1731, LTH 1735, LTH 2585, and LTH 2586 were sequenced. The partial 16S rRNA sequences of Lactobacillus sp. strains LTH 1731, LTH 1735, LTH 2585, and LTH 2586 were identical to the corresponding regions of the complete 16S rRNA primary structure of Lactobacillus sp. strain LTH $2587^{\mathrm{T}}$ and different from the sequences of all other strains. rRNA sequence similarity values are shown in Table 2 . Figure 2 shows a phylogenetic tree that was based on the 16S rRNA sequence data and reflects the phylogenetic position of $L$. pontis sp. nov.

Design of oligonucleotide probes. A comparison of the $16 \mathrm{~S}$ rRNA sequences of lactobacilli and other reference organisms revealed diagnostic regions which could be used to design oligonucleotide probes for rapid specific identification of lactobacilli isolated from sourdough. The sequences and specificities of these probes, as well as the hybridization and washing temperatures used to achieve selective hybridization, are summarized in Table 3.

Hybridization studies. The specificities of the oligonucleotide probes were evaluated in dot blot hybridizations experiments performed with nucleic acids isolated from the bacterial strains listed in Table 1 . The type strains used to design the probes served as controls. In addition, nucleic acids obtained from well-characterized sourdough lactobacilli and strains preliminarily characterized as Lactobacillus sp. were hybridized. The results are summarized in Table 1 . The probes hybridized to the type strains and other strains their respective species. No cross-reactions were observed with members of other Lactobacillus species isolated from sourdough. However, Lactobacillus homohiochii DSM $20571^{\mathrm{T}}$ hybridized with the probe derived from the rRNA of $L$. fructivorans. Lactobacillus spp. strains LTH 2588 and LTH 2584 were identified as $L$. brevis and $L$. reuteri strains, respectively, whereas Lactobacillus sp. strains LTH 2590, LTH 2594, LTH 2595, and LTH 2598 were identified as strains of $L$. sanfrancisco. These findings were subsequently confirmed by physiological data. The probe designed for $L$. pontis specifically detected $L$. pontis LTH 1731, LTH 1735 , LTH 2585, LTH 2586, and LTH $2587^{\mathrm{T}}$ and did not react with the nucleic acids of the other strains investigated.

Protein pattern analysis. The soluble proteins patterns were determined for selected strains and compared with the patterns for strains in a data base containing normalized wholecell protein patterns of representative strains belonging to most species of lactic acid bacteria. Lactobacillus spp. strains LTH 2588 and LTH 2584 were confirmed to be $L$. brevis and $L$. reuteri strains, respectively, and the patterns of Lactobacillus sp. strains LTH 2590, LTH 2594, and LTH 2595 were similar to the pattern of one of the strains of $L$. sanfrancisco. The protein patterns of all $L$. pontis strains were similar but differed from those of other lactobacilli. The position of these strains is shown in the dendrogram in Fig. 1.

Physiological characterization of $L$. pontis. The taxonomically relevant physiological features of $L$. pontis strains are summarized in Table 4. L. pontis LTH 2585 and LTH 2586 fermented only fructose and ribose, and thus this pattern did

TABLE 4. Differential characteristics of L. pontis sp. nov. and other sourdough lactobacilli

\begin{tabular}{|c|c|c|c|c|c|c|c|c|c|c|c|c|c|c|c|c|c|c|c|c|c|}
\hline \multirow[b]{2}{*}{ Strain(s) } & \multirow[b]{2}{*}{ 萢 } & \multirow{2}{*}{ 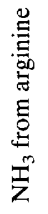 } & \multirow{2}{*}{$\begin{array}{l}0 \\
\text { in } \\
\vdots \\
\vdots \\
5 \\
0 \\
0 \\
0 \\
0\end{array}$} & \multirow{2}{*}{ 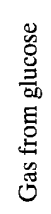 } & \multicolumn{15}{|c|}{ Utilization of: } & \multirow{2}{*}{ 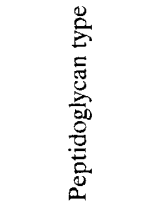 } & \multirow{2}{*}{ 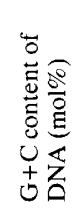 } \\
\hline & & & & & 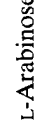 & 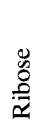 & $\begin{array}{l}\stackrel{y}{0} \\
\frac{0}{2} \\
\dot{b}\end{array}$ & 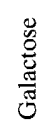 & 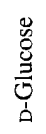 & 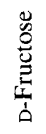 & 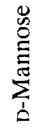 & 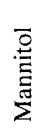 & 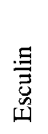 & 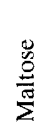 & 总 & $\frac{\mathscr{y}}{\frac{\mathscr{O}}{0}}$ & 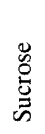 & 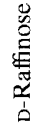 & 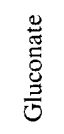 & & \\
\hline L. sanfrancisco ATCC $27651^{\mathrm{T}}$ & $\mathrm{D}, \mathrm{L}$ & - & + & + & - & + & - & $+^{a}$ & + & - & - & - & - & + & - & - & . & - & 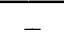 & Lys-Ala & $36-38$ \\
\hline L. fructivorans DSM $20203^{\mathrm{T}}$ & $\mathrm{D}, \mathrm{L}$ & + & + & + & - & + & - & - & + & + & - & - & - & - & - & - & - & - & + & Lys-D-Asp & $38-41$ \\
\hline L. fermentum DSM $20052^{\mathrm{T}}$ & $\mathrm{D}, \mathrm{L}$ & + & - & + & - & + & - & + & + & + & + & + & + & + & + & + & + & + & + & Orn-D-Asp & $52-54$ \\
\hline L. brevis DSM $20054^{\mathrm{T}}$ & $\mathrm{D}, \mathrm{L}$ & + & + & + & + & + & + & + & + & + & - & - & - & + & - & + & - & - & - & Lys-D-Asp & $44-47$ \\
\hline $\begin{array}{l}\text { L. pontis LTH } 1731 \text { and LTH } \\
1735\end{array}$ & $\mathrm{D}, \mathrm{L}$ & + & + & + & - & + & - & + & + & + & - & - & - & + & + & + & - & + & - & Orn-D-Asp & $53-56$ \\
\hline $\begin{array}{l}\text { L. pontis LTH } 2585 \text { and LTH } \\
2586\end{array}$ & $\mathrm{D}, \mathrm{L}$ & + & + & $-b$ & - & + & - & - & - & + & - & - & - & - & - & - & - & - & - & Orn-D-Asp & 53 \\
\hline L. pontis LTH $2587^{\mathrm{T}}$ & $\mathrm{D}, \mathrm{L}$ & + & + & $-{ }^{b}$ & - & + & - & - & - & + & - & - & - & + & - & - & + & + & + & Orn-D-Asp & $\mathrm{ND}^{c}$ \\
\hline L. reuteri LTH 2584 & $\mathrm{D}, \mathrm{L}$ & + & + & + & - & + & - & - & + & - & - & - & - & + & + & + & - & + & - & Lys-D-Asp & ND \\
\hline L. reuteri DSM $20016^{\mathrm{T}}$ & $\mathrm{D}, \mathrm{L}$ & + & - & + & + & + & - & + & + & + & - & - & - & + & + & + & + & + & ND & Lys-D-Asp & $40-42$ \\
\hline
\end{tabular}

${ }^{a}$ Galactose utilization was not observed in this study but has been described by Kandler and Weiss (8)

${ }^{b}$ L. pontis LTH 2585, LTH 2586, and LTH $2587^{\mathrm{T}}$ do not utilize glucose but produce gas from fructose.

${ }^{c} \mathrm{ND}$, not determined. 
not correspond to the sugar fermentation pattern of any previously described Lactobacillus species. L. pontis LTH 1731, LTH 1735, and LTH $2587^{\text {T }}$ fermented additional carbohydrates. Analysis of the cell wall revealed the presence of ornithine and aspartic acid in L. pontis LTH 1731, LTH 1735, LTH 2585, LTH 2586, and LTH $2587^{\mathrm{T}}$, which is consistent with an Orn-D-Asp peptidoglycan type. The DNA G+C contents of L. pontis LTH 1735 and LTH $2587^{\mathrm{T}}$ were determined to be $54.7 \pm 1.4$ and $53.3 \pm 0.2 \mathrm{~mol} \%$, respectively. L. pontis can clearly be separated physiologically from the closely related taxon $L$. reuteri and other lactobacilli on the basis of its sugar fermentation pattern, high DNA $\mathrm{G}+\mathrm{C}$ content, and peptidoglycan type. As determined by light microscopy, L. pontis cells are slender and occur in long chains which may be bent or may even resemble vine tendrils. Figure 3 shows phasecontrast photomicrographs of cells of $L$. pontis LTH 1735 and LTH $2587^{\mathrm{T}}$. Electron micrographs of L. pontis LTH $2587^{\mathrm{T}}$ revealed that the tendril-like forms are associations of bent cells which stick together because of surface layers or polysaccharides (Fig. 4). This "matrix" may be responsible for the difficulties encountered in obtaining pure cultures of $L$. pontis and physically separating $L$. pontis from strains of $L$. sanfrancisco.

\section{DISCUSSION}

The genus Lactobacillus includes 55 species (5), and, therefore, a polyphasic approach and thorough taxonomic research are necessary before a new species can be described. We confirmed that the major fermenting organisms in the preparations which we examined were strains of $L$. brevis, $L$. fructivorans, L. fermentum, and L. sanfrancisco, and we also found that strains of $L$. pontis accounted for a large percentage of the microbial flora. In some sourdough preparations the concentration of L. pontis LTH 2585 or L. pontis LTH 2586 was $2.7 \times 10^{9} \mathrm{CFU} / \mathrm{g}$, and the concentration of $L$. pontis LTH $2587^{\mathrm{T}}$ was $2.2 \times 10^{9} \mathrm{CFU} / \mathrm{g}$; these organisms accounting for approximately $80 \%$ of the lactobacilli. Some of these strains utilize only a very limited number of carbohydrates and live in close association with $L$. sanfrancisco, from which they are difficult to separate physically.

We used a combination of DNA data, physiological characteristics, and protein patterns in a general strategy to describe a microbial population (in this case a sourdough population), which resulted in a reliable taxonomic classification of the microorganisms and a determination of the phylogenetic relationships of the bacteria. In addition to identification of a previously unknown species, the development and use of oligonucleotide probes allowed us to quantitatively analyze the microflora of sourdough at all stages of fermentation reliably.

Description of Lactobacillus pontis sp. nov. Vogel, Böcker, Stolz, Ehrmann, Fanta, Ludwig, Pot, Kersters, Schleifer, and Hammes. Stolz, Ehrmann, Fanta, Ludwig, Pot, Kersters, Schleifer, and Lactobacillus pontis Vogel, Böcker, Hammes (pon'tis. L. gen. n. pons, bridge, referring to BRIDGE, which is the abbreviation for the Commission of European Communities Research Programme entitled Biotechnology Research for Innovation, Development and Growth in Europe; during this program the organism was isolated and characterised by the joint efforts of workers in three laboratories).

Cells are nonmotile, nonsporing, gram-positive, slender rods (diameter, 0.3 to $0.6 \mu \mathrm{m}$; length, 4 to $6 \mu \mathrm{m}$ ) that occur singly, in pairs, and in chains. Some strains have a strong tendency to form chains of long bent rods; the chains may even resemble a vine tendril. After 2 to 5 days of anaerobic incubation at $30^{\circ} \mathrm{C}$ colonies on sanfrancisco agar are 1 to $2 \mathrm{~mm}$ in diameter; these
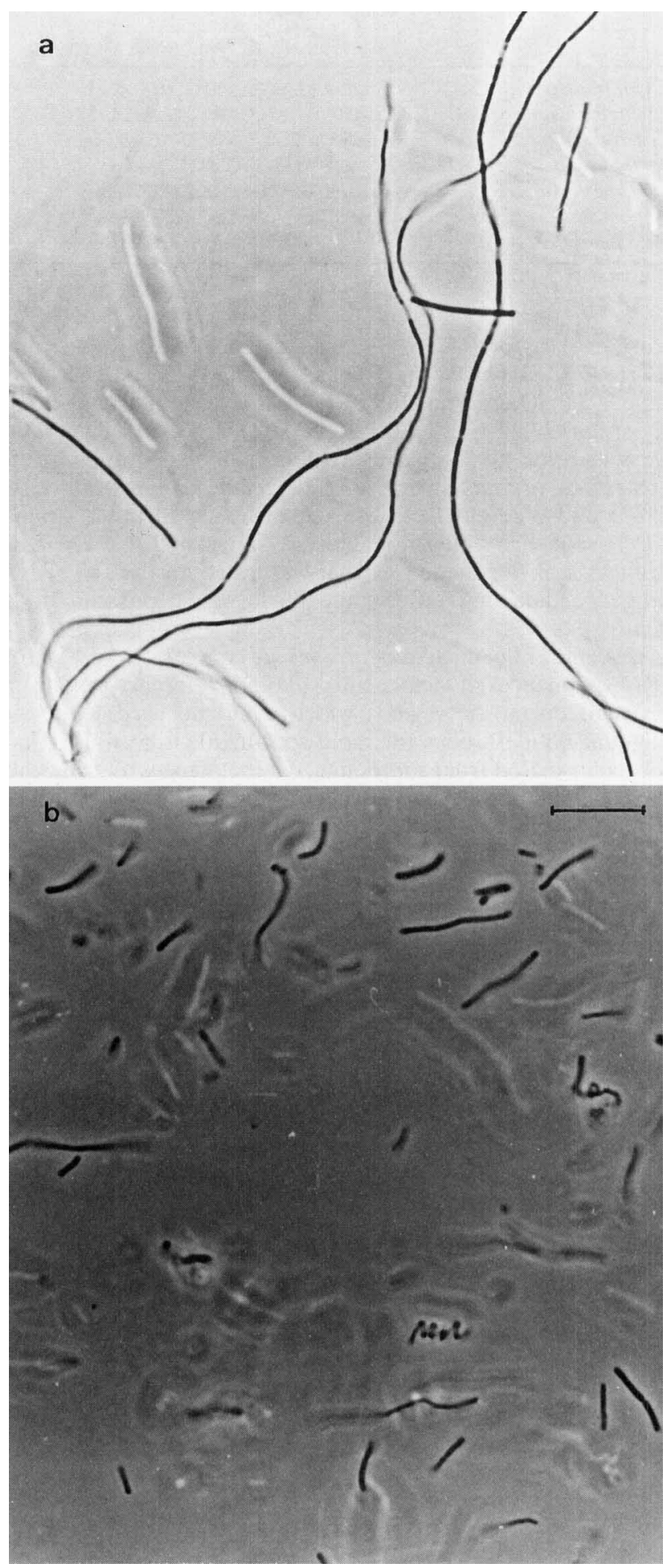

FIG. 3. Phase-contrast photomicrographs of cells of $L$. pontis LTH 1735 (a) and LTH $2587^{\mathrm{T}}$ (b). The cells were grown in sanfrancisco medium. Magnification, $\times 800$. Bar $=10 \mu \mathrm{m} . L$. pontis LTH 1735 forms long chains of slender cells (a), whereas strain LTH $2587^{\mathrm{T}}$ also forms vine tendril-like associations (b) (see Fig. 4). 


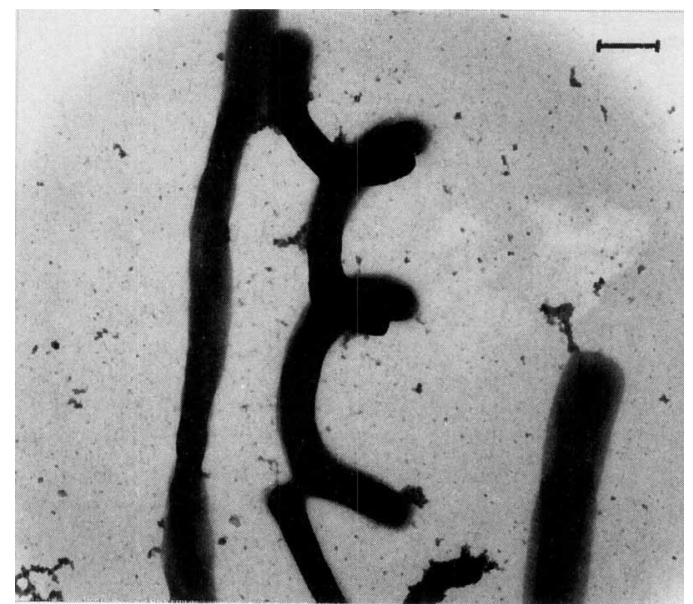

FIG. 4. Electron micrograph of L. pontis LTH $2587^{\mathrm{T}}$. Magnification, $\times 12,000$. Bar $=0.6 \mu \mathrm{m}$. Formvar-coated EM grids were used with dried, nonstained cells that had been suspended in a solution containing $1 \mathrm{~g}$ of tryptone per liter and $8.5 \mathrm{~g}$ of $\mathrm{NaCl}$ per liter and fixed with $1 \%$ glutaraldehyde. The micrograph was taken with an energyfiltering model CEM 902 transmission electron microscope (Zeiss). The vine tendril-like appearance is due to chain formation by single bent cells.

colonies are rough circular plateaus that have irregular borders and smooth convex centers and are translucent and greyish. All strains grow at 15 and $45^{\circ} \mathrm{C}$. The main fermentation products from maltose or fructose are lactate, acetate, ethanol, glycerol, and $\mathrm{CO}_{2}$. Catalase activity is not detected.

The terminal $\mathrm{pH}$ in sanfrancisco medium ranges from 3.9 to 4.2. All strains ferment ribose and fructose. L. pontis LTH $2587^{\mathrm{T}}$ also ferments maltose. In addition, L. pontis LTH 1731 and LTH 1735 ferment galactose, glucose, lactose, melibiose, and raffinose. All strains cleave arginine. The type strain is strain LTH 2587 (= DSM $8475=$ LMG 14187). Strain LTH 1735 (= DSM $8476=$ LMG 14188) is a reference strain that exhibits different characteristics. The DNA G+C contents of L. pontis LTH 1735 and LTH $2587^{\mathrm{T}}$ are $54.7 \pm 1.4$ and $53.3 \pm$ $0.2 \mathrm{~mol} \%$, respectively. Both strains were originally isolated from rye sourdough and can be predominant in some batches.

\section{ACKNOWLEDGMENTS}

This work was supported by the BRIDGE project of the European Community [Contract BIOT-CT91-0263 (SSMA)].

We thank K.-H. Körtje (Hohenheim, Germany) for preparing the electron micrograph.

\section{REFERENCES}

1. Beinert, W.-D., A. Meisner, M. Fuchs, E. Riedel, M. Lüpke, and $\mathbf{H}$. Brückner. 1992. OPA oder FMOC? Aminosäureanalyse mit dem Roboter-Autosampler. GIT Fachz. Lab. 36:1018-1027.

2. Böcker, G., R. F. Vogel, and W. P. Hammes. 1990. Lactobacillus sanfrancisco als stabiles Element in einem Reinzucht-SauerteigPräparat. Getreide Mehl Brot 44:269-274.

3. de Rijk, P., J. M. Neefs, Y. van der Peer, and R. de Wachter. 1992. Compilation of small ribosomal subunit RNA sequences. Nucleic Acids Res. 20:2075-2089.
4. Felsénstein, J. 1982. Numerical methods for inferring phylogenetic trees. Q. Rev. Biol. 57:379-404.

5. Hammes, W. P., and R. F. Vogel. The genus Lactobacillus. In B. J. B. Wood and W. H. Holzapfel (ed.), The lactic acid bacteria, vol. 2. The genera of lactic acid bacteria, in press. Elsevier, Amsterdam, The Netherlands.

6. Hammes, W. P., N. Weiss, and W. Holzapfel. 1992. Lactobacillus and Carnobacterium, p. 1535-1594. In A. Balows, H. G. Trüper, M. Dworkin, W. Harder, and K. H. Schleifer (ed.), The Prokaryotes, 2nd ed. Springer Verlag, New York.

7. Hertel, C., W. Ludwig, M. Obst, R. F. Vogel, W. Hammes, and K. H. Schleifer. 1991. 23S rRNA-targeted oligonucleotide probes for the rapid identification of meat lactobacilli. Syst. Appl. Microbiol. 14:173-177.

8. Kandler, O., and N. Weiss. 1986. Regular, nonsporing grampositive rods, p. 1208-1260. In P. H. A. Sneath, N. S. Mair, M. E. Sharpe, and J. G. Holt (ed.), Bergey's manual of systematic bacteriology, vol. 2. Williams and Wilkins, Baltimore.

9. Kersters, K., and J. De Ley. 1975. Identification and grouping of bacteria by numerical analysis of their electrophoretic patterns. J. Gen. Microbiol. 87:333-342.

10. Kline, L., and T. F. Sugihara. 1971. Microorganisms of the San Francisco sourdough bread process. II. Isolation and characterization of undescribed bacterial species responsible for the souring activity. Appl. Microbiol. 21:102-110.

11. Laemmli, U. K. 1970. Cleavage of structural proteins during the assembly of the head of bacteriophage T4. Nature (London) 227:680-685.

12. Lewington, J., S. P. Greenaway, and B. J. Spillane. 1987. Rapid small scale preparation of bacterial genomic DNA, suitable for cloning and hybridisation analysis. Lett. Appl. Microbiol. 5:51-53.

13. Olsen, G. J., R. Overbeek, N. Larsen, T. L. Marsh, M. J. McCoughey, M. A. Maciukenas, W. M. Kuan, T. J. Macke, Y. Xing, and C. R. Woese. 1992. The ribosomal database project. Nucleic Acids Res. 20(Suppl.):2199-2200.

14. Pot, B., P. Vandamme, and K. Kersters. 1994. Analysis of electrophoretic whole-organism protein fingerprints, p. 493-551. In M. Goodfellow and A. G. O'Donnel (ed.), Chemical methods in procaryotic systematics. J. Wiley and Sons, Chichester, England.

15. Schillinger, U. 1985. Verwandschaftsbeziehungen innerhalb der Milchsäurebakterien. Ph.D. thesis. Technische Universität München, Munich.

16. Schleifer, K. H., and O. Kandler. 1972. Peptidoglycan types of bacterial cell walls and their taxonomic implications. Bacteriol. Rev. 36:407-477.

17. Sneath, P. H. A., and R. R. Sokal. 1973. Numerical taxonomy. The principles and practice of numerical classification. Freeman, San Francisco.

18. Spicher, G. 1984. Die Mikroflora des Sauerteiges. XXII. Mitt.: Weitere Untersuchungen über die Zusammensetzung und die Variabilität der Mikroflora handelsüblicher Sauerteigstarter. Z. Lebensm. Unters. Forsch. 178:106-109.

19. Spicher, G., and R. Schröder. 1978. Die Mikroflora des Sauerteiges. IV. Mitt.: Untersuchungen über die Art der in "Reinzuchtsauern" anzutreffenden stäbchenförmigen Milchsäurebakterien (Genus Lactobacillus Beijerinck). Z. Lebensm. Unters. Forsch. 167:342-354.

20. Vauterin, L., and P. Vauterin. 1992. Computer-aided objective comparison of alactrophoretic patterns for grouping and identification of microorganisms. Eur. Microbiol. 1:37-41.

21. Weiss, N., and U. Schillinger. 1984. Lactobacillus sanfrancisco sp. nov., nom. rev. Syst. Appl. Microbiol. 4:507-511.

22. Weizenegger, M., M. Neumann, E. Stackbrandt, and W. Ludwig. 1991. Eubacterium alactolyticum phylogenetically groups with Eubacterium limnosum, Acetobacterium woodii and Clostridium barkeri. Syst. Appl. Microbiol. 15:32-36. 